\title{
Menggunakan Model Discovery Learning Untuk Meningkatkan Hasil Belajar Geografi Di Sma Negeri 1 Loghia Di Muna
}

\author{
Hasmin $^{1}$, Ramli $^{2}$ \\ ${ }^{12}$ Program Studi Pendidikan Geografi Universitas Halu Oleo \\ Email: monsterhalus@gmail.com
}

(Received: Agustus 2019; Reviewed: Agustus 2019; Accepted: September 2019; Published: September 2019)

Ini adalah artikel dengan akses terbuka dibawah license CC BY-NC-4.0 (C2019 oleh penulis (https://creativecommons.org/licenses/by-nc/4.0/ ).

\begin{abstract}
SMAN 1 Loghia is one of school at Regency Muna who becomes researcher research object because the learning outcomes are still low, This is because only $40 \%$ meet the KKM. The purpose of this research: (1) To know student studying activities at SMA Country 1 Loghia who is taught by applying model discovery Learning; (2) To know activity teach teachers at SMA Country 1 Loghia who is taught by applying model discovery Learning; (3) To know result step-up study students at SMA Country 1 Loghia who is taught by applying model discovery Learning. The data in this research an quantitative and qualitative data which obtained from observation sheets and learning test result. Acquired observational result that by applying model discovery Learning: (1) activity study student increase with score average 3,2 get categories well; (2) activity teach to learn increase by scores average 3,6 get categories well; (3) result study student geography braze $x$ IIS3 SMAN 1 Loghia increases from an average score of 60 to an average score of 80 , with learned thoroughness $84 \%$ which is $\geq 75$ according to the criteria for completing teaching determined by the school.
\end{abstract}

Key words: Discovery Learning, Geography, Learning Outcomes, SMA Negeri 1 Loghia, Muna

\begin{abstract}
ABSTRAK
SMAN 1 Loghia adalah salah satu sekolah di Kabupaten Muna yang menjadi objek penelitian peneliti karena hasil belajarnya yang masih rendah, hal ini dikarenakan hanya 40\% yang memenuhi KKM. Tujuan penelitian:(1) Untuk mengetahui aktivitas belajar siswa di SMA Negeri 1 Loghia yang diajar dengan menerapkan model Discovery Learning (2) Untuk mengetahui aktivitas mengajar guru di SMA Negeri 1 Loghia yang diajar dengan menerapkan model Discovery Learning (3) Untuk mengetahui peningkatan hasil belajar siswa di SMA Negeri 1 Loghia yang diajar dengan menerapkan model Discovery Learning. Data dalam penelitian adalah data kualitatif dan kuantitatif yang diperoleh dari lembar observasi dan tes hasil belajar. Hasil penelitian diperoleh bahwa dengan menerapkan model Discovery Learning: (1) aktivitas belajar siswa meningkat dengan skor rata-rata 3,2 berkategori baik. (2) aktivitas mengajar guru meningkat dengan skor rata-rata 3,6 berkategori baik. (3) hasil belajar geografi siswa Kelas X IIS3 SMAN 1 Loghia
\end{abstract}


meningkat dari rata-rata skor 60 menjadi rata-rata skor 80, dengan ketuntasan belajar $84 \%$ yang $\geq 75$ sesuai dengan KKM yang ditentukan sekolah.

Kata Kunci: Discovery Learning, Geografi, Hasil Belajar, SMA Negeri 1 Loghia, Muna

\section{PENDAHULUAN}

Indonesia merupakan Negara kepulauan yang memiliki potensi cukup besar, kaya dengan keanekaragaman yang begitu menjanjikan. Pendidikan merupakan suatu cara pembentukan kemampuan manusia untuk menggunakan akal fikiran/rasional juga merupakan usaha sadar yang sengaja dirancang untuk mencapai tujuan yang telah ditetapkan. Salah satu tujuan pendidikan yaitu untuk meningkatkan kualitas sumber daya manusia. Melalui pendidikan yang baik, kita akan mudah mengikuti perkembangan zaman dimasa yang akan datang, khususnya perkembangan dalam bidang Ilmu Pengetahuan dan Teknologi (IPTEK).

Berhasilnya suatu tujuan pendidikan tergantung pada bagaimana proses belajar mengajar yang dialami oleh siswa. Belajar adalah suatu proses yang kompleks terjadi pada diri setiap orang sepanjang hidupnya. Proses belajar itu terjadi karena adanya interaksi antara seorang dengan lingkunganya. Belajarpun terjadi kapan dan dimana saja. Salah satu tanda seseorang telah belajar adalah adanya perubahan tingkah laku karena pengetahuan, keterampilan, atau sikapnya (Azhar, 2014). Selain itu, Belajar adalah kegiatan berproses dan merupakan unsur yang sangat fundamental dalam penyelengaraan jenis dan jenjang pendidikan, pencapaian tujuan pendidikan sangat tergantung pada keberhasilan proses belajar siswa di sekolah dan lingkungan sekitarnya (Jihad dan Haris, 2013).

SMAN 1 Loghia adalah salah satu sekolah di Kabupaten Muna. Berdasarkan hasil observasi awal dalam kegiatan pembelajarannya, guru masih banyak didominasi penggunaan model pembelajaran Kontekstual. Pada dasarnya model pembelajaran kontekstual merupakan model yang menekankan pada proses keterlibatan siswa secara penuh untuk menemukan materi dan menghubungkanya dengan konteks kehidupan sehari-hari. Namum, menurut salah satu guru geografi SMA Negeri 1 Loghia, model pembelajaran tersebut masih susah dilakukan oleh siswa, tidak semua siswa dapat mengaitkan materi pembelajran dengan kontoks kehidupan sehari-hari. Dilihat dari sarana prasarana sekolah mampu untuk mendukung pembelajaran. Hanya saja siswa belum mampu mengikuti pembelajaran yang menggunakan model pembelajaran kontekstual. Selain itu hasil belajar siswa kelas X IIS3 SMAN 1 Loghia masih rendah. Hal ini dilihat dari hasil ulangan harian menunjukan bahwa siswa yang belum tuntas 12 dan 13 yang tuntas dari 25 jumlah siswa, batas ketuntasannya yaitu 75 sebagai nilai KKM yang di tetapkan sekolah.

Menurut Dimyati dan Mudjiono (2013) "hasil belajar merupakan hasil dari suatu interaksi tindak belajar dan tindak mengajar. Dari sisi guru, tindak mengajar diakhiri dengan proses evaluasi hasil belajar. Dari sisi siswa, hasil belajar merupakan berakhirnya penggal dan puncak proses belajar".

Berdasarkan hasil observasi awal tersebut diperlukan perbaikan yang dapat mendorong siswa untuk aktif dalam mengikuti proses pembelajaran Geografi. 
Adapun upaya yang dapat dilakukan untuk meningkatkan kualitas proses dan hasil pembelajaran geografi adalah dengan membuat variasi model pembelajaran salah satunya yaitu menerapkan Model Pembelajaran Discovery Learning.

Penemuan (discovey) merupakan suatu model pembelajaran yang dikembangkan berdasarkan pandangan kontrukstivisme. Menurut Kurniasih dan Sani (2014:64) discovery learning didefinisikan sebagai proses pembelajaran yang terjadi bila materi pembelajaran tidak disajikan dalam bentuk finalnya, tetapi diharapkan siswa mengorganisasi sendiri. Selanjutnya, Sani (2014:97) mengungkapkan bahwa discovery adalah menemukan konsep melalui serangkaian data atau informasi yang diperoleh melalui pemecahan masalah.

$$
\text { Pernyataan lebih lanjut }
$$

dikemukakan oleh Hosnan (2014:282) bahwa discovery learning adalah suatu model untuk mengembangkan cara melajar aktif dengan menemukan/memecahkan sendiri maka hasil yang diperoleh akan setia dan tahan lama dalam ingatan. Melalui belajar penemuan, siswa juga bisa belajar berpikir dan mencoba memecahkan sendiri masalah yang dihadapi. Wilcox (Hosnan, 2014:281) menyatakan bahwa dalam pembelajaran dengan penemuan, siswa didorong untuk Model discovery merupakan pembelajaran yang menekankan pada pengalaman langsung dan pentingnya pemahaman struktur atau ide-ide penting terhadap suatu disiplin ilmu, melalui keterlibatan siswa secara aktif dalam pembelajaran. Bahan ajar yang disajikan dalam bentuk pertanyaan atau permasalahan yang harus diselesaikan. Jadi siswa memperoleh pengetahuan yang belum diketahuinya tidak melalui pemberitahuan, melainkan melalui pemikiran sendiri. Sardiman (dalam Kemendikbud, 2013b:4) mengungkapkan bahwa dalam mengaplikasikan model discovery learning guru berperan sebagai pembimbing dengan memberikan kesempatan kepada siswa untuk belajar secara aktif, guru harus dapat membimbing dan mengarahkan kegiatan belajar siswa sesuai tujuan.

Menindaklanjuti

beberapa pendapat yang telah dikemukakan oleh para ahli, maka peneliti menyimpulkan bahwa model discovery learning adalah suatu proses pembelajaran yang dimana siswa dituntut untuk terlibat secara aktif untuk menemukan/memecahkan masalah sendiri yang diberikan oleh guru.

Langkah-langkah penerapan model discovery learning: (1) langkah persiapan mencakup menentukan tujuan pembelajaran, mengidentifikasi, memilih materi, dan menentukan topic (2) pelaksanaan mencakup stimulation, problem statement, pengumpulan data, pengolahan data, pembuktian, menarik kesimpulan (Syah, 2004).

\section{METODE \\ Jenis Penelitian}

Jenis penelitian adalah Penelitian Tindakan Kelas (PTK) adalah suatu penelitian yang dilakukan dengan model discovery learning yang bertujuan untuk mengatasi masalah pola fikir siswa/I pada materi pokok dinamika litosfer dan dampaknya terhadap kehidupan dikelas $\mathrm{X}$ IIS3 SMA Negeri 1 Loghia dalam mata pelajaran geografi.

\section{Tempat dan Waktu Penelitian}

Penelitian ini bertempat di SMA Negeri 1 Loghia Desa Waara, Kecamatan Lohia Kabupaten Muna, waktu penelitian pada semester genap 2018/2019.

\section{Subjek Penelitian}

Subjek penelitian ini adalah guru dan siswa kelas X IIS3 SMA Negeri 1 Loghia. Jumlah siswa sebanyak 25 orang yang terdiri dari 12 orang laki-laki dan 13 orang 
perempuan.

\section{Teknik pengumpulan data}

Teknik pengumpulan data dalam penelitian ini adalah (1) data mengenai aktivitas siswa diambil dengan menggunakan lembar observasi dengan cara memberikan skor pada aspek aktivitas yang dilakukan untuk siswa sesuai dengan kriteria yang telah ditentukan. (2) data mengenai hasil belajar geografi diambil dengan menggunakan tes hasil belajar (tes siklus) dengan bentuk tes berupa tes essay yang mencakup semua indikator pembelajaran pada siklus I serta siklus II.

\section{Teknik Analisis Data}

Data dalam penelitian ini dianalisis dengan menggunakan statistik deskriptif, baik secara kualitatif maupun kuantitatif. Analisis deskriptif kualitatif digunakan untuk memberikan penjelasan mengenai aktivitas belajar siswa dan aktivitas mengajar guru selama proses pembelajaran berlangsung. Analisis deskriptif kuantitatif digunakan untuk menyajikan angka-angka (skor) persentase aktivitas guru dalam mengelola pembelajaran, persentase aktivitas belajar siswa dan persentase ketuntasan hasil belajar siswa. Adapun langkah-langkah yang digunakan dalam menganalisis data tersebut dapat dikembangkan sebagai berikut:

a) Menentukan hasil belajar siswa:

$X_{i}=\frac{s p i}{s m} \times 100$ (Usman dan Setiawati, 2001)

Keterangan:

$X_{i}=$ Nilai yang diperoleh siswa ke-i

Spi $=$ Skor yang diperoleh siswa ke-i

$\mathrm{Sm}=$ Skor maksimum yang mungkin dicapai (skor ideal)

b) Menentukan tingkat pencapaian ketuntasan belajar :

$$
\% \text { Tuntas }=\frac{\sum T B}{N} X 100 \%
$$

Keterangan:

$\sum T B=$ Jumlah Siswa yang tuntas belajar

$\mathrm{N}=$ Jumlah Siswa secara keseluruhan

Nilai Klasikal $=\frac{\text { Nilai rata-rata }}{\text { nilai ideal }} \times 100 \%$

( Sudjana, $2002: 67$ )

C) Keberhasilan aktivitas mengajar guru dengan rumus:

$\%$ KAMG $=\frac{\text { Jumlah skor perolehan siswa }}{\text { Jumlah skor maksimum }} \times$ 100\% (Mulyasa, 2003: 112)

d. Menghitung nilai rata-rata hasil belajar siswa dengan rumus:

$\bar{X}=\frac{\sum_{i=1}^{n} X_{i}}{n}$ (Sudjana, 2002: 67)

Keterangan:

$\mathrm{X}^{-}=$nilai rata-rata yang diperoleh siswa

$\mathrm{n}=$ jumlah siswa secara keseluruhan

$\mathrm{Xi}=$ nilai yang diperoleh tiap siswa

\section{HASIL DAN PEMBAHASAN \\ Pelaksanaan Tindakan siklus I \\ Perencanaan}

Hal-hal yang dilakukan pada tahap perencanaan ini adalah: 1) menyiapkan RPP sesuai dengan model discovery learning untuk pertemuan I dan peretmuan II, 2) menyiapkan lembar kerja siswa (LKS 01 dan LKS 02), 3) mempersiapkan sumber, bahan, dan alat bantu yang dibutuhkan, 4) menyiapkan lembar observasi pebelajaran (format observasi siswa dan guru), 5) menyusun soal evaluasi tes hasil belajar siswa berupa essay.

\section{Pelaksanaan Tindakan}

Pelaksanaan tindakan pada siklus I dilaksanakan dalam dua kali pertemuan sesuai dengan RPP.

\section{Aktivitas siswa pertemuan I dan II siklus I}

Gambaran rata-rata aktivitas siswa dengan menerapkan model pembelajaran discovery learning pada siklus I untuk setiap aspek aktivitas yang dinilai dapat dilihat pada Gambar $\quad 3.1 \quad$ berikut: 


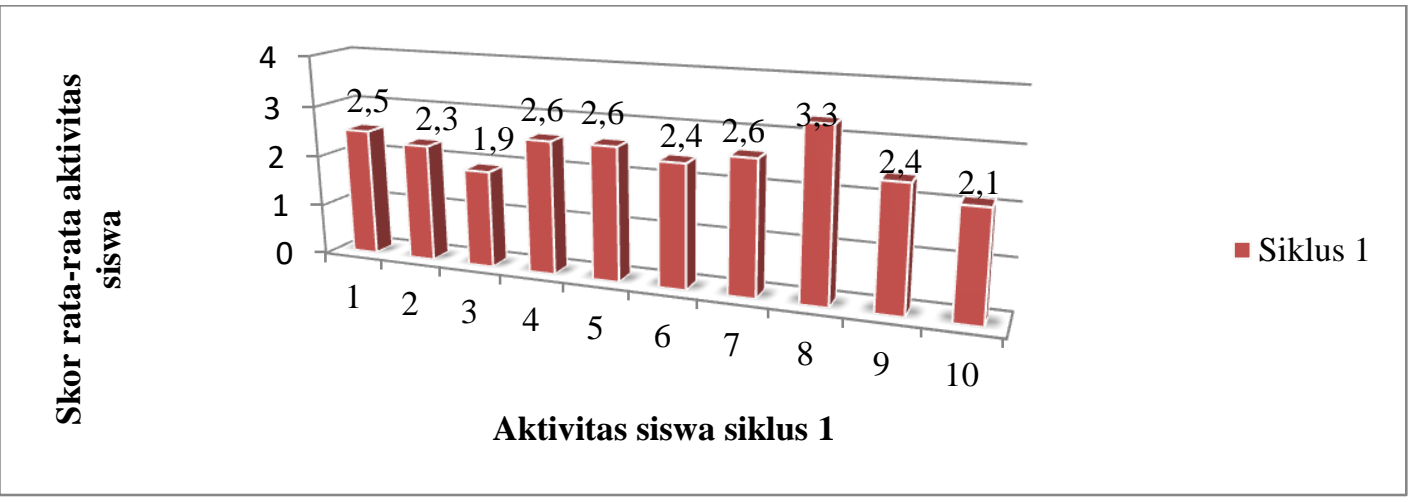

Gambar 1. Grafik Skor Rata-Rata Aktivitas Siswa Pada Siklus I (Analisis Data Primer, 2019)

Keterangan:

1. Mendengarkan atau memperhatikan guru dalam menyampaikan langkah persiapan pembelajaran.

2. Siswa mendengar dan memperhatikan penjelasan guru serta tayangan video mengenai materi pembelajaran.

3. Siswa untuk mengidentifikasi masalah dengan menjawab pertanyaan kelompok lain lalu menjawab pertanyaan tersebut sebagai hipotesis.

4. Siswa memecahkan masalah sesuai dengan petunjuk LKS.

5. Siswa mengumpulkan informasi atau data dari berbagai sumber dengan membaca buku atau mencari internet untuk menjawab pertanyaan yang telah dirumuskan.

6. Siswa melakuan diskusi mengenai lembar kerja yang telah dibagikan.

7. Siswa untuk memeriksa kembali jawaban yang ada pada LKS dan membuktikan benar atau tidaknya jawaban yang mereka ajukan yang dicatat sebagai hipotesis.

8. Masing-masing perwakilan kelompok siswa untuk mempresentasikan hasil diskusi.

9. Siswa menanggapi pemaparan dari kelompok lainya.

10. Siswa membuat kesimpulan bersama kelompoknya.

Berdasarkan gambar di atas tentang hasil observasi aktivitas siswa dapat diperoleh gambaran bahwa, hasil aktivitas siswa tersebut masih belum memenuhi kriteria ketuntasan minimal yaitu 3,0 karena rata-rata aktivitas siswa masih mencapai rata-rata 2,5 yang berkategorikan cukup. Dimana pada siklus I aktivitas siswa yang mendapatkan skor terendah dengan nilai rata-rata sebesar 1,9 adalah aktivitas nomor 3 yaitu siswa untuk mengidentifikasi masalah dengan menjawab pertanyaan kelompok lain lalu menjawab pertanyaan tersebut sebagai hipotesis. Sedangkan aktivitas siswa yang mendapat skor tertinggi adalah aktivitas nomor 8 yaitu masing-masing kelompok mempresentasikan hasil diskusi didepan kelas dengan nilai 3,3.

Rata-rata aktivitas siswa selama pembelajaran pada siklus I pertemuan I dan II dapat dilihat pada Gambar 2 berikut :

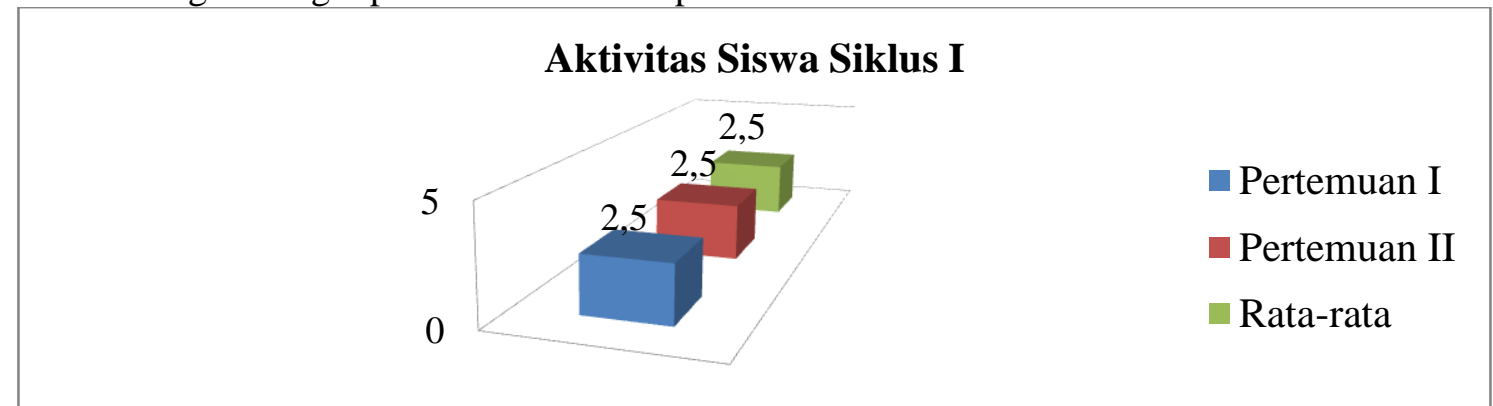

Gambar 2. Grafik Skor Rata-Rata Aktivitas Siswa Siklus I Pertemuan 1 Dan 2 
(Analisis Data Primer, 2019)

Berdasarkan gambar 3.2 di atas, dapat dikatakan bahwa aktivitas siswa di siklus I masih tergolong cukup hal itu dikarenakan belum mencapai batas ketuntasan yang di tetapkan yaitu $\geq 3,0$.

2. Aktivitas mengajar guru pertemuan I dan II siklus I
Gambaran rata-rata aktivitas mengajar guru dalam proses pembelajaran dengan menggunakan model pembelajaran discovery learning pada materi dinamika litosfer dan dampaknya terhadap kehidupan yang diperoleh dengan menggunakan lembar observasi aktivitas guru pada siklus I dapat dilihat pada gambar 3 berikut :

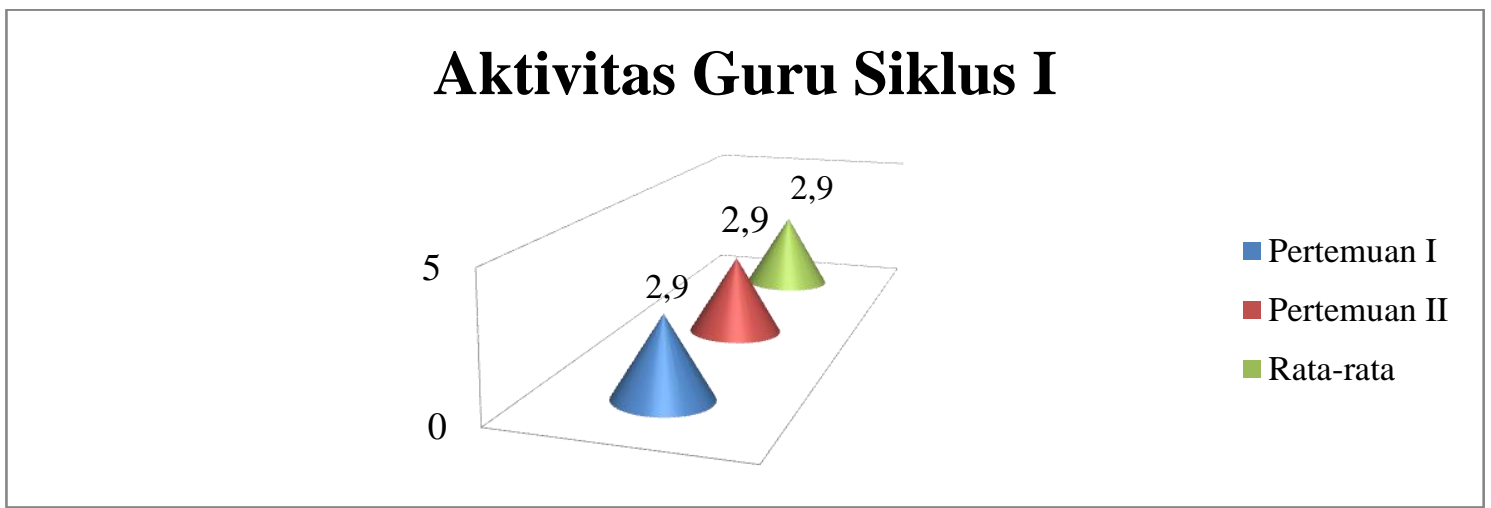

Gambar 3. Grafik Skor Rata-Rata Aktivitas Guru Siklus I (Analisis Data Primer, 2019)

Berdasarkan gambar 3.3 di atas menunjukkan bahwa, aktivits guru masih belum memenuhi kriteria ketuntasan minimal yaitu 3,0 karena aktivitas guru masih mencapai rata-rata 2,9 yang berkategorikan cukup.

\section{Hasil belajar siswa pertemuan I dan II siklus I}

Untuk hasil belajar siswa pada siklus I diperoleh melalui tes yang diberikan di akhir pertemuan siklus dan dapat dilihat melalui tabel berikut:

Tabel 1. Data anlisis ketuntasan hasil belajar siswa pada siklus I

\begin{tabular}{|c|c|c|c|}
\hline Skor & $\begin{array}{c}\text { Jumlah } \\
\text { siswa }\end{array}$ & Persentase & Ketuntasan belajar \\
\hline $0-74$ & 10 & $40 \%$ & Belum Tuntas \\
\hline $75-100$ & 15 & $60 \%$ & Sudah Tuntas \\
\hline Jumlah & 25 & $100 \%$ & \\
\hline \multicolumn{4}{|c|}{ Keterangan } \\
\hline Tuntas & & & 15 orang \\
\hline Tidak Tuntas & & & 10 orang \\
\hline Nilai rata-rata & & & 74 \\
\hline Nilai maksimum & & & 93 \\
\hline Nilai minimum & & & 40 \\
\hline Persentase ketuntasan & & & $60 \%$ \\
\hline
\end{tabular}

Sumber: Analisis Data Primer, 2019.

Data di atas menunjukan bahwa hasil belajar siswa pada siklus I yang memperoleh skor antara 0-74 berjumlah 10 orang dengan persentase $40 \%$, sedangkan siswa yang memperoleh skor 75-100 berjumlah 15 orang dengan persentase mencapai $60 \%$, namun itu belum mencapai indikator ketuntasan keberhasilan yaitu $80 \%$ siswa yang mencapai ketuntasan hasil belajar. Untuk lebih jelasnya gambaran hasil belajar yang sudah tuntas dan yang belum tuntas siklus I dapat dilihat pada gambar 4 berikut: 


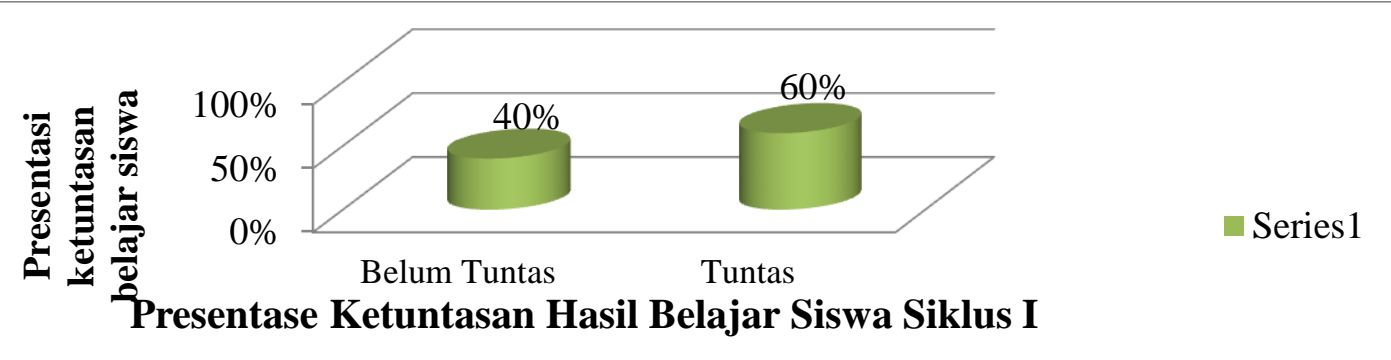

Gambar 4. Presentase Ketuntasan Hasil Belajar Siswa Siklus I (Analisis Data Primer, 2019)

Oleh karena di siklus I hipotesis tindakan penelitian belum tercapai maka perlu dilanjutkan kesiklus II dengan tujuan mencari jawaban atas hipotesis.

\section{Pelaksanaa tindakan siklus II Perencanaan}

Setelah mengetahui kekurangan yang terjadi pada siklus I baik yang dilakukan oleh siswa maupun guru, maka pada pembelajaran siklus II guru mencoba memperbaiki kesalahan yang dilakukan sebelumnya, sehingga hasil belajar dengan menerapkan model discovery learning dapat tercapai sesuai indikator keberhasilan yaitu $80 \%$.

\section{Pelaksanaan tindakan}

Pelaksanan tindakan pada siklus II dilaksanakan dalam dua kali pertemuan sesuai RPP.

\section{Aktivitas belajar siswa pertemuan I dan II siklus II}

Gambaran rata-rata aktivitas siswa dengan menerapkan model pembelajaran discovery learning pada siklus II untuk setiap aspek aktivitas yang dinilai dalam dua pertemuan dapat dilihat pada Gambar 5 berikut:

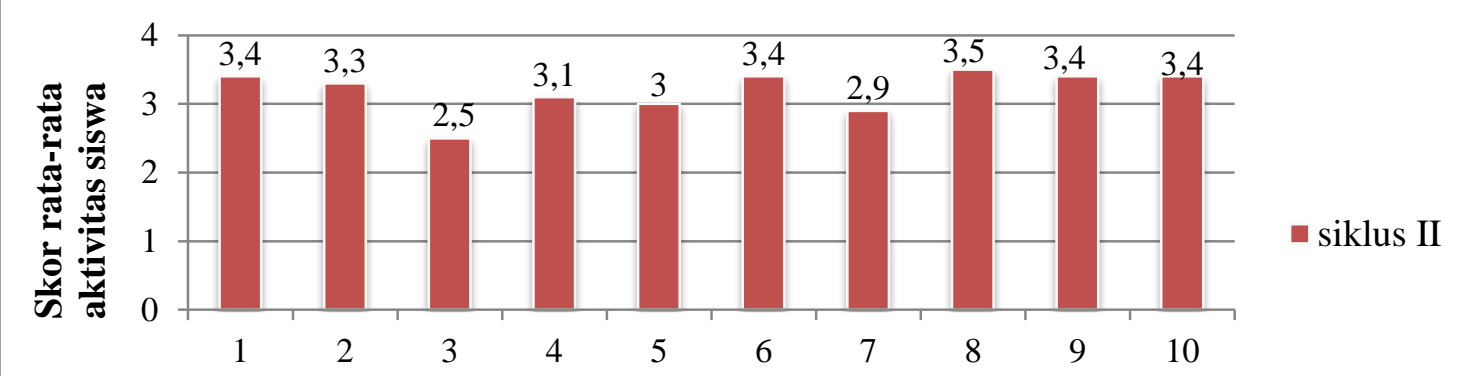

Aktivitas siswa siklus II

Gambar 5. Grafik skor rata-rata aktivitas siswa pada siklus II (Analisis Data Primer, 2019)

Keterangan:

1. Mendengarkan atau memperhatikan guru dalam menyampaikan langkah persiapan pembelajaran.

2. Siswa mendengar dan memperhatikan penjelasan guru serta tayangan video mengenai materi pembelajaran.

3. Siswa untuk mengidentifikasi masalah dengan menjawab pertanyaan kelompok lain lalu menjawab pertanyaan tersebut sebagai hipotesis.
4. Siswa memecahkan masalah sesuai dengan petunjuk LKS.

5. Siswa mengumpulkan informasi atau data dari berbagai sumber dengan membaca buku atau mencari internet untuk menjawab pertanyaan yang telah dirumuskan.

6. Siswa melakukan diskusi mengenai lembar kerja yang telah dibagikan.

7. Siswa untuk memeriksa kembali jawaban yang ada pada LKS dan 
membuktikan benar atau tidaknya jawaban yang mereka ajukan sebagai hipotesis.

8. Masing-masing perwakilan kelompok siswa untuk mempresentasikan hasil diskusi.

9. Siswa menanggapi pemaparan dari kelompok lainya.

10. Siswa membuat kesimpulan bersama kelompoknya.

Untuk mendapatkan gambaran rata-rata aktivitas siswa siklus II selama pembelajaran dapat dilihat pada gambar 6 berikut:

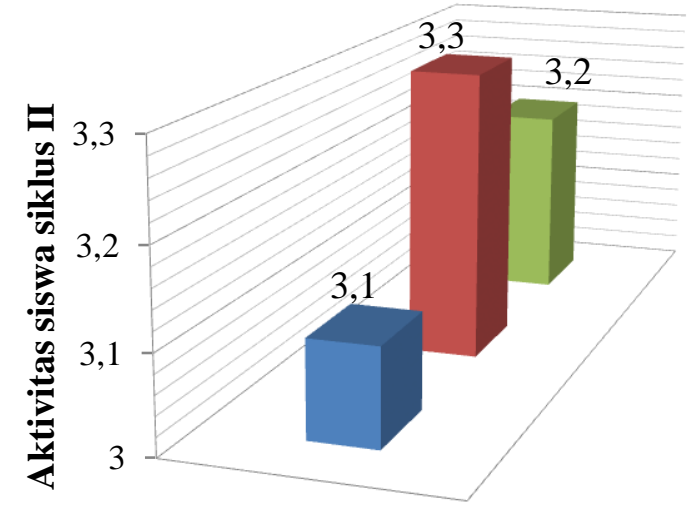

- Pertemuan I

- Pertemuan II

Rata-rata

Gambar 6. Grafik skor rata-rata aktifitas siswa siklus II pertemuan 1 dan 2 (Analisis Data Primer, 2019)

Berdasarkan gambar 3.6 di atas menunjukan bahwa, aktivitas siswa telah memenuhi kriteria ketuntasan minimal yaitu 3,0. Dimana aktivitas siswa telah mencapai rata-rata 3,2 yang berkategorikan baik.

\section{Aktivitas mengajar guru pertemuan II dan II siklus II}

Gambaran rata-rata aktivitas mengajar guru dalam proses pembelajaran dengan menggunakan model Discovery Learning pada materi dinamika litosfer dan dampaknya terhadap kehidupan yang diperoleh dengan menggunakan lembar observasi aktivitas guru pada siklus I dapat dilihat pada gambar 7 berikut:

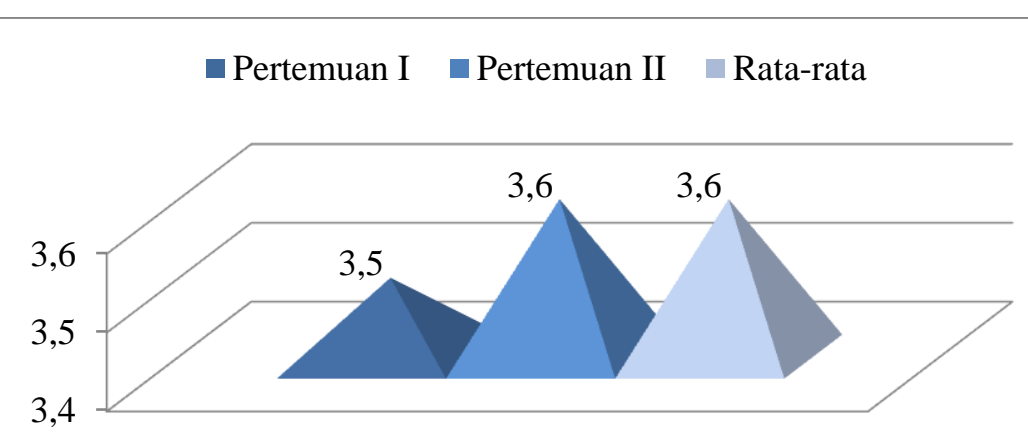

Aktivitas Guru Siklus II

Gambar 7. Grafik skor rata-rata aktivitas guru pada siklus II (Analisis Data Primer, 2019)

Berdasarkan gambar 7 di atas menunjukkan bahwa, aktivitas guru telah memenuhi kriteria ketuntasan minimal yaitu 3,0 karena aktivitas gruru telah mencapai rata-rata 3,6 yang berkategorikan baik.

\section{Hasil belajar siswa pertemuan I dan II siklus II}


Untuk hasil belajar siswa pada siklus II diperoleh melalui tes yang diberikan di akhir pertemuan siklus dan dapat dilihat melalui tabel berikut:

Tabel 2. Data Anlisis Ketuntasan Hasil Belajar Siswa Pada Siklus II

\begin{tabular}{lccc}
\hline \multicolumn{1}{c}{ Skor } & Jumlah Siswa & Persentase & Ketuntasan Belajar \\
\hline $0-74$ & 4 & $16 \%$ & Belum Tuntas \\
$75-100$ & 21 & $84 \%$ & \\
Jumlah & 25 & $100 \%$ & Sudah Tuntas \\
\hline \multicolumn{5}{c}{ Keterangan } \\
\hline Tuntas & & 21 orang & \\
Tidak Tuntas & & 4 orang & \\
Nilai rata-rata & & 80 & \\
Nilai maksimum & & 93 & \\
Nilai minimum & & 60 & \\
Persentase ketuntasan & & & \\
\hline
\end{tabular}

Sumber : Analisis Data Primer, 2019.

Untuk mendapatkan gambaran hasil belajar tuntas pada siklus II dapat dilihat pada gambar siswa yang sudah tuntas dan yang belum 8 berikut:

Gambar 8. Presentase Hasil Belajar Siswa Siklus II

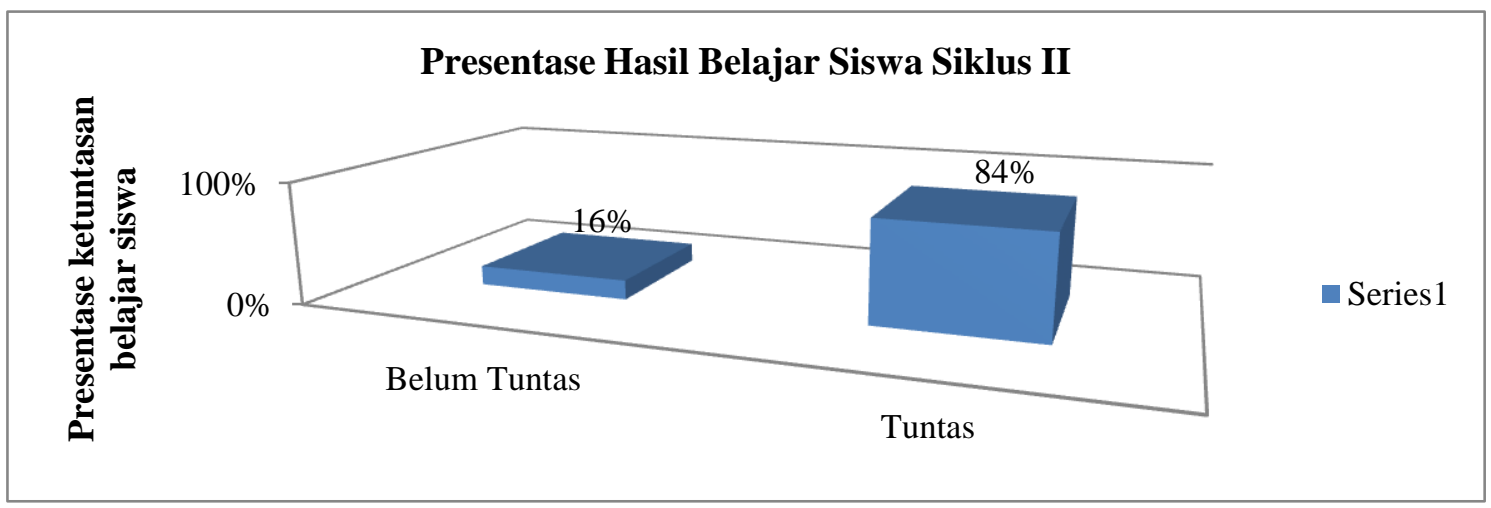

Dari tabel 2 dan gambar 8 di atas menunjukan bahwa ketuntasan belajar siswa pada siklus II yang memperoleh skor antara 074 berjumlah 4 dari 25 siswa dengan persentase $16 \%$. Sedangkan siswa yang memperoleh skor antara 75-100 berjumlah 21 dari 25 siswa dengan persentase ketuntasan $84 \%$. Hasil ini sudah lebih baik jika dibandingkan dengan skor perolehan siswa siklus I. Dengan demikian indikator ketuntasan belajar siswa telah tercapai dan itu artinya penelitian ini berhasil karena secara klasikal kriteria ketuntasan yang di tetapkan sebagai indikator berhasilnya pembelajaran yaitu $80 \%$ sudah terpennuhi.

\section{PEMBAHASAN}

1. Aktivitas Belajar Siswa Selama Pembelajaran Berlangsung

Berdasarkan hasil pengamatan pada dua siklus baik itu siklus I maupun siklus II aktivitas belajar siswa menunjukan peningkatan ke arah yang lebih baik. Hal itu tentu dipengaruhi oleh semangat yang besar oleh siswa dalam mencapai hasil yang optimal.

Pada siklus I berdasarkan hasil analisis deskriptif terhadap aktivitas siswa menunjukan skor rata-rata sebesar 2,5 yang berkategori cukup. Hal tersebut dikarenakan masih ada beberapa aktivitas siswa yang tergolong kurang optimal. Berdasarkan hasil refleksi siklus I ditemukan ada beberapa aktivitas siswa yang belum terlaksana dengan baik salah satunya siswa untuk 
mengidentifikasi masalah dengan menjawab pertanyaan kelompok lain lalu menjawab pertanyaan tersebut sebagai hipotesis, kurang bekerja sama dalam menyelesaikan tugas kelompok. Oleh karena masih belum optimalnya aktivitas belajar siswa maka diperlukan perbaikan pada siklus selanjutnya. Pada siklus II dari hasil analisis deskriptif terhadap skor rata-rata aktivitas siswa mengalami peningkatan yang sangat signifikan dari aktivitas siswa siklus I. Dimana skor rata-rata aktivitas siswa pada siklus II sebesar 3,2 yang berkategorikan baik.

\section{Aktivitas Mengajar Guru Selama Pembelajaran Berlangsung}

Berdasarkan hasil pengamatan pada dua siklus baik itu siklus I maupun siklus II, untuk aktivitas mengajar guru menunjukan peningkatan ke arah yang lebih baik. Hal itu tentu dipengaruhi oleh semangat yang besar oleh guru dalam mencapai hasil yang optimal.

Pada siklus I berdasarkan analisis deskiptif aktivitas mengajar guru menunjukan skor rata-rata sebesar 2,9 yang berkategorikan cukup. Hal itu tentu dipengaruhi oleh adanya beberapa aktivitas yang belum terlaksana secara optimal. Hasil refleksi aktivitas mengajar guru pada siklus 1 yang masih rendah diantaranya adalah: guru menyampaikan tujuan pembelajaran dan memberikan penjelasan tentang manfaat menguasai materi pembelajaran, guru membimbing siswa mengolah dan menganalisis data dari setiap pertanyaan pada LKS, Guru mengevaluasi terhadap hasil diskusi siswa, guru memberikan soal latihan atau tugas untuk dikerjakan dirumah.

Berdasarkan hasil refleksi tersebut maka diperlukan pembenahan, agar diperoleh peningktan aktivitas mengajar guru sesuai dengan kriteria ketuntasan yang telah ditetapkan. Pembenahan tersebut dilakukan pada siklus II, pada siklus II berdasarkan hasil analisis deskriptif menjelaskan bahwa aktivitas mengajar guru mengalami peningkatan yang signifikan dengan skor ratarata sebesar 3,6 yang berkategori baik.

Dengan demikian, dapat disimpulkan bahwa aktivitas belajar siswa dan aktivitas mengajar guru selama proses pembelajaran dari siklus I sampai siklus II mengalami peningkatan. Dengan data ini pula dapat disebutkan bahwa dengan menerapkan Model discovery learning dapat meningkatkan aktivitas belajar siswa dan aktivitas mengajar guru selama proses pembelajaran geografi pada siswa kelas X IIS3 SMAN 1 Loghia.

\section{Hasil Belajar Siswa}

Hasil belajar siswa pada siklus I yang memperoleh skor antara 0-74 berjumlah 10 orang dengan persentase $40 \%$, sedangkan siswa yang memperoleh skor 75-100 berjumlah 15 orang dengan persentase mencapai $60 \%$, namun itu belum mencapai indikator ketuntasan keberhasilan yaitu $80 \%$ siswa yang mencapai ketuntasan hasil belajar. Rendahnya hasil belajar siswa ini di sebakan karena Siswa belum terbiasa dengan model pembelajaran discovery learning terkhusus pada kegiatan diskusi. Siswa masih malu mengungkapkan pendapatnya dalam proses pembelajaran yang sedang berlangsung. Selain aktivitas siswa terdapat aktivitas guru yang masih kurang optimal seperti kurang memberikan kesempatan kepada siswa untuk bertanya terkait materi yang di pelajarai saat proses pembelajaran berlangsung, Guru belum maksimal memberikan kesimpulan secara singkat tentang materi yang telah di presentasikan siswa.

Tabel 3. Data Anlisis Ketuntasan Hasil Belajar Siswa Pada Siklus I

\begin{tabular}{cccc}
\hline Skor & Jumlah siswa & Persentase & Ketuntasan belajar \\
& & & \\
\hline $0-74$ & 10 & $40 \%$ & Belum Tuntas \\
$72-100$ & 15 & $60 \%$ & Sudah Tuntas \\
Jumlah & 25 & $100 \%$ & \\
\hline
\end{tabular}

Sumber: Analisis Data Primer, 2019.

Setelah melakukan analisis dan

kentuntasan siswa secara klasikal belum refleksi hasil belajar siswa I bahwa mencapai target maka guru mata pelajaran 
bersama dengan peniliti mecoba melakukan perbaikan pada proses pembelajaran pada siklus selanjutnya. Pada siklus selanjutnya dalam hal ini siklus II ketuntasan belajar siswa diperoleh skor antara 0-75 berjumlah 4 dari 25 siswa dengan persentase $16 \%$. Sedangkan siswa yang memperoleh skor antara 75-100 berjumlah 21 dari 25 siswa dengan persentase ketuntasan $84 \%$. Hasil ini sudah lebih baik jika dibandingkan dengan skor perolehan siswa siklus I. Dengan demikian indikator ketuntasan belajar siswa telah tercapai dan itu artinya hasil penelitian ini berhasil karena secara klasikal kriteria ketuntasan yang di tetapkan sebagai indikator berhasilnya pembelajaran yaitu $80 \%$ sudah terpenuhi.

Tabel 4. Data Anlisis Ketuntasan Hasil Belajar Siswa Pada Siklus II

\begin{tabular}{cccc}
\hline Skor & Jumlah siswa & Persentase & Ketuntasan belajar \\
\hline $0-74$ & 4 & $16 \%$ & Belum Tuntas \\
$72-100$ & 21 & $84 \%$ & Sudah Tuntas \\
\hline Jumlah & $\mathbf{2 5}$ & $\mathbf{1 0 0 \%}$ & \\
\hline
\end{tabular}

Sumber: Analisis Data Primer, 2019.

Peningkatan hasil belajar pada siklus II ini menunjukan pula bahwa telah ada peningkatan hasil belajar siswa dan guru telah mampu mengelola pembelajaran. Pada Siklus II target ketuntasan hasil belajar telah tercapai yaitu $84 \%$ siswa telah tuntas hasil belajarnya. Dengan peningkatan ini, penelitian ini telah berhasil mencapai target dan keberhasilan siswa dalam test siklus II memberi gambaran penerapan model discoveri learning mampu meningkatkan hasil belajar siswa kelas X IIS3 SMAN 1 Loghia.

\section{SIMPULAN DAN SARAN}

\section{Simpulan}

Berdasarkan hasil dalam penelitian ini dapat ditarik beberapa kesimpulan sebagai berikut:

1. Aktivitas belajar siswa dengan menerapkan model pembelajaran Discovery Leaarning pada setiap siklus cenderung meningkat. Hal ini ditunjukan dengan skor rata-rata pada setiap siklusnya. Pada siklus I skor rata-rata aktivitas siswa adalah 2,5 dikategorikan cukup dan meningkat pada siklus II menjadi 3,2 yang berkategori baik.

2. Aktivitas mengajar guru dengan menerapkan model pembelajaran Discovery Learning pada setiap siklus cenderung meningkat. Hal ini ditunjukan dengan skor rata-rata pada setiap siklusnya. Pada siklus I skor rata-rata mengajar guru adalah 2,9 dikategorikan cukup dan meningkat pada siklus II menjadi 3,6 yang berkategori baik.

3. Hasil belajar geografi siswa Kelas $X$ IIS3 SMAN 1 Loghia meningkat setelah menerapkan model pembelajaran Discovery Learning, sebesar $84 \%-60 \%=24 \%$. Dimana pada siklus I nilai rata-rata hasil belajar siswa sebesar 74, ketuntasan belajar secara klasikal yang dicapai adalah sebesar $60 \%$, pada siklus II nilai rata-rata hasil belajar siswa meningkat menjadi 80, ketuntasan belajar secara klasikal yang dicapai juga meningkat menjadi $84 \%$, dengan persentase peningkatan sebesar $24 \%$.

\section{SARAN}

Adapun saran yang dapat peneliti sampaikan yaitu, antara lain:

1. Bagi sekolah, khususnya SMAN 1 Loghia dapat mencoba menerapkan model pembelajaran discovery learning ini dalam meningkatkan hasil belajar siswa serta dalam meningkatkan kualitaas belajar siswa selama proses pembelajaran.

2. Bagi peneliti selanjutnya, teruslah belajar dan menggali informasi lebih 
jauh tentang model pembelajaran discovery learning untuk mempertajam kemampuan dalam menerapkan model ini pada kesempatan-kesemptan berikutnya agar memberikan hasil yang jauh lebih optimal.

3. Peneliti menyadari bahwa di dalam perencanaan penelitian, pelaksanaan penelitian dan penganalisaan data hasil penelitian sampai pada penarikan kesimpulan masih ada kekurangankekurangan baik dari segi penulisan termasuk penggunaan kata didalamnya. Hal itu karena peneliti hanyalah manusia biasa yang tidak sempurna dean tidak pernah luput dari kesalahan. Olehnya itu peneliti mengharapkan saran kritik yang bersifat konstruktif untuk kebaikan pada penulisanpenulisan berikutnya.

\section{DAFTAR RUJUKAN}

Azhar, Arsyad. 2014. Media Pembelajaran. Jakarta: PT. Raja Grafindo Persada.

Dimyati dan Mudjiono. 2013. Belajar Dan Pembelajaran. Jakarta: Rineka Cipta.

Hosnan. 2014. Pendekatan Saintik dan Kontekstual dalam Pembelajaran Abad 21. Bogor: Ghalia Indonesia.

Jihad, Asep, Haris, Abdul. 2013. Evaluasi Pembelajaran. Yogyakarta: Multi Press Indo.

Kemendikbud. 2013. Kerangka Dasar Kurikulum 2013. Kementerian Pendidikan dan Kebudayaan Direktorat Jenderal Pendidikan Dasar. Jakarta.

Mulyasa. 2003. Kurikulum Berbasis Kompetensi. Bandung: Remaja Rosdakarya.

Sani. 2014. Pembelajaran Saintik Untuk Kurikulum 2013. Jakarta: Bumi Aksara.

Sudjana. 2002. Metode Statistika. Bandung: Tarsito.

Syah, Muhibbin. 2004. Psikologi Pendidikan. Bandung: Rosda Karya.

Usman, Moh. Uzer dan Lilis Setiawati. 2001. Upaya Optimalisasi Kegiatan Belajar Mengajar. Bandung: Remaja Rosdakarya.
Editor In Chief

Rosmini Maru

rosminimaru@unm.ac.id

\section{Publisher}

Geography Education, Postgraduate Program, Universitas Negeri Makassar Jl. Bonto Langkasa Gunungsari Baru Makassar, 90222 Kampus PPs UNM Makassar Gedung AB ruang 01, Indonesia Email : ugj@unm.ac.id

\section{Info Berlangganan Jurnal}

\section{9 / Ihsan}

